\title{
RECENT LITERATURE AND BOOK REVIEWS
}

\section{P.J. Mundy}

BAMFORD, A. J., MONADJEM, A., DIEKMANN, M. \& HARDY, I. C.W. (2009). Development of non-explosive-based methods for mass capture of vultures. South African Journal of Wildlife Research 39: 202-208.

Investigated methods of launching nets, powered by black powder, detonators, elastic, and compressed air, and a walk-in trap. The last proved most effective at capturing birds, needed no licence, but took a long time to construct and of course was barely portable.

(email for Monadjem: ara@uniswacc.uniswa.sz)

BIRD, J. P. \& BLACKBURN, T. M. (2011). Observations of large raptors in northeast Sudan. Scopus 31: 19-27.

From a $430 \mathrm{~km}$ transect (Atbara to Port Sudan) and other ad hoc observations, in January 2010, three species of vulture were seen. Thirty Egyptian Vultures on the transect, counts of 21 and 24 Lappet-faced Vultures at a carcass and one Hooded Vulture, were noted.

(email: jezbird@gmail.com)

BREWSTER, C. A \& TYLER, S. J. (2012). Summary of category B records. Babbler 57: 45-47.

Many sightings are listed for the Cape, Lappet-faced, White-headed and Hooded Vultures, but no ages. In the Tswapong Hills, no nests of the Cape Vulture were seen at Lerala, but 76 were seen at Moremi Gorge. On p. 57 many sightings are listed of the White-backed Vulture, from singles up to groups of about 70 .

( $\%$ BLB, Box 26691, Gaborone) 
BRUCE-MILLER, I. (2008). Martial Eagle Polemaetus bellicosus apparently killing White-headed Vulture Trigonoceps occipitalis. Bulletin African Bird Club 15: 102-103.

Just as it says! In the end the eagle ate some of the vulture. The two colour photos are not very clear.

BUSSIERE, E. \& WIJERS, M. (2013). Foraging frenzy: more than 50 raptors at a termite swarm. Ornithological Observations 4: 11-18b.

In January 2009, four Hooded Vultures, Tawny and Steppe Eagles, and 50 or so Yellow-billed Kites arrived at a termite emergence.

(email: elsa.bussiere@uct.ac.za)

BUTLER, J. R. A. \& du TOIT, J. T. (2002). Diet of free-ranging domestic dogs (Canis familiaris) in rural Zimbabwe: implications for wild scavengers on the periphery of wildlife reserves. Animal Conservation 5: 29-37.

Dogs were measured at 7.2 per $\mathrm{km}^{2}$, and increasing in the Communal Land at $6.5 \%$ p.a. Being both diurnal and nocturnal, and physically dominant, they monopolized carrion and seriously out-competed vultures in the CL. This scenario will intensify.

(email: research@speyfisheryboard.com)

CHOMBA, C., M'SIMUKO, E. \& NYIRENDA, V. (2013). Patterns of nest placement of lappet faced vulture (Torgos tracheliotos) in Lochinvar National Park, Kafue Flats, Zambia. Open Journal of Ecology 3: 431-437.

Of 22 possible trees, five were confirmed as Lappet-faced Vulture nesting sites. Average nest height was $10 \mathrm{~m}$. All five were photographed (and included in the article) and all 22 were mapped.

(email: chansachomba@ rocketmail.com) 
DEMEY, R. (ed.) (2004). Recent Reports. Bulletin African Bird Club 11: 7079.

Unconfirmed Rüppell's Griffon in the Okavango, Botswana. Single Bearded Vultures seen in Egypt's south-east corner; group of 50+, 65 and 35+ Lappet-faced vultures at Shalatein in May to September. A Eurasian Griffon was seen flying in Ethiopia.

(email: rondemey@compuserve.com)

DEMEY, R. (ed.) (2012). Recent Reports. Bulletin African Bird Club 19: 94110.

Six Lappet-faced Vultures were seen at Bir Shalatayn, south-east Egypt; an immature Hooded Vulture at Naivasha, Kenya ("this species...has decreased dramatically in recent years"); and three Rüppell's Griffons at Aousserd, southern Western Sahara (is this the first sighting for this country?).

(email: rondemey1@gmail.com)

DEMEY, R. (ed.) (2013). Recent Reports. Bulletin African Bird Club 20: 216230.

Egyptian Vultures were seen in Botswana (an immature), in Cape Verde Islands (two adults and two immatures), in Tsavo East of Kenya (five), and in the south of the Kruger National Park in South Africa (one). A tagged Cape Griffon was seen in Gonarezhou National Park in Zimbabwe. An immature Palmnut Vulture fed on a carcass in South Africa.

(email: rondemey1@gmail.com)

DIES, J. I., LORENZO, J. A., GUTIÉRREZ, R. et al. (2009). Observaciones de aves raras en Espaňa, 2007. Ardeola 56: 309-344.

(p. 320) Three sightings of Rüppell's Griffon, each of a single immature, on the Spanish side of the Strait. The note states the difficulty of 
separating this species from the Eurasian Griffon, particularly with juveniles and immatures (!).

(email: jidies@ hotmail.com)

GRIFFITHS, C. S., BARROWCLOUGH, G. F., GROTH, J. G. \& MERTZ, L. A. (2007). Phylogeny, diversity, and classification of the Accipitridae based on DNA sequences of the RAG-1 exon. Journal Avian Biology 38: 587-602.

This large nuclear gene was sampled from many raptor genera, including nine genera of Old World Vultures. Pairwise sequence divergence was as low as $0.07 \%$ between Aegypius and Torgos ( $=2$ base pairs of 2872 bp sequenced!). Six genera formed a monophyletic clade, named subtribe Gypina, with Gyps and Necrosyrtes being closest relatives. A second monophyletic clade, subtribe Gypaetina, comprised Gypaetus and Neophron (close relatives) with Gypohierax and Polyboroides.

(email: cgriff@liu.edu)

GUTIÉRREZ, R., LORENZO, J. A., et al. (2013). Observaciones de aves raras en Espaňa, 2011. Ardeola 60: 437-506.

(p.455) Third record of a White-backed Vulture in Spain, one immature seen in September at Algeciras. Nine Rüppell's Griffons were sighted from March to November, at least seven being immatures. To date there have been 76 griffons seen, though no doubt including duplicates.

(email: rarezas@seo.org)

JACK, J. P. \& DEGEFE, A. (2008). Field notes of raptors in and around Mertule Mariam, Gojjam Province, northwest Ethiopia. Scopus 28: 31-36.

Three sites were surveyed on a total of 42 days from December 2001 to April 2002, at an altitude of $2500 \mathrm{~m}$. Six vulture species were seen: two Bearded, six Egyptian, many Hooded (up to 57 at the abattoir), many 
White-backed (43 on a donkey carcass), 17 Rüppell's Griffon and six White-headed.

(email: joelprashant@gmail.com)

KEYS, G. J., JOHNSON, R. E., VIRANI, M. Z. \& OGADA, D. (2013). Results of a pilot survey of raptors in Dzanga-Sangha Special Reserve, Central African Republic. Gabar 24: 64-82.

The survey was done in February-March 2011, in this section of rainforest. Of the 20 species sighted in 118 hours, Palm-nut Vultures were common, with 25 records out of 198 . Only one immature was seen.

(email for Munir Virani: tpf@africaonline.co.ke)

MALLALIEU, M. (2013). Bird observations around Juba, South Sudan. Bulletin African Bird Club 20: 156-176.

Four species were seen around Juba in 2010-2012. Hooded Vultures roosted in the town, but not found nesting; far away 150 were at a roost in Rumbek. Whitewash was seen at a cliff to the south-east - of Rüppell's Griffon? White-backed and White-headed Vultures were seen in small numbers.

(email: Markpat123@btinternet.com)

MARGALIDA, A., BERTRAN, J., BOUDET, J. \& HEREDIA, R. (2004). Hatching asynchrony, sibling aggression and cannibalism in the Bearded Vulture Gypaetus barbatus. Ibis 146: 386-393.

By means of video cameras at five nests in the eastern Pyrenees, in 20002002, the incubation period of the first-laid egg averaged 53 days, and a little more for the second-laid egg. Hatching asynchrony was an estimated six days. The elder chick persistently attacked the younger. The younger chick died of starvation facilitated by the elder's aggression.

(email: margalida@gauss.entorno.es) 
MOLINA, B., PRIETA, J. et al. (2009). Noticiario Ornitológico. Ardeola 56: 345-367.

(pp. 351-2). Sightings are listed of all four species in Spain. Highlights were: 50 pairs of Egyptian Vulture at a productivity of 0.64 young per pair on Menorca; an "irruption" of Eurasian Griffons on the Balearics with 68 seen on Menorca and 51 on Mallorca; 15 pairs of Cinereous Vulture on Mallorca produced 9 fledglings, and the October census found 123 individuals!

(email: noticiario@seo.org)

MOLINA, B., PRIETA, J., LORENZO, J. A. \& LÓPEZ-JURADO, C. (2012). Noticiario Ornitológico. Ardeola 59: 413-453.

A Eurasian Griffon ringed in Màlaga was found dead on Formentera (Balearics) two months later. Groups of 45 Griffons were seen twice in and around Mallorca in 2011. The Cinereous Vulture had a record 16 pairs in the Tramuntana Mountains in Mallorca, fledging ten chicks.

(email: noticiario@seo.org)

MOLINA, B., PRIETA, J., LORENZO, J. A. \& LÓPEZ-JURADO, C. (2013). Noticiario Ornitológico. Ardeola 60: 507-543.

(p. 517). One nest of a Eurasian Griffon in Monfragüe had a small chick and an unhatched egg. For the first time in Mallorca the species bred: four nests. Two birds soared over Menorca. A census in 2013 in Extremadura of the Cinereous Vulture found 837 pairs that bred: 577 fledglings came from 768 nests. In Mallorca in 2012, 17-18 pairs produced 12 fledglings. (email: noticiario@seo.org)

MORENO-OPO, R., ARREDONDO, A. \& GUIL, F. (2010). Foraging range and diet of cinereous vulture Aegypius monachus using livestock resources in central Spain. Ardeola 57: 111-119. 
The study used the origin of 377 cattle ear tags (most were on pigs!) collected at a colony in Ciudad Real Province in the years 2004-2008. Total area covered was nearly $67000 \mathrm{~km}^{2}$ whereas the foraging range of individuals was $1522 \mathrm{~km}^{2}$.

(email: ruben.moreno-opo@cbd-habitat.com)

MUNDY, P. J. \& ROCKINGHAM-GILL, D. V. (2013). Anomalies among White-headed Vultures. Honeyguide 59: 122-123, 140.

Three plumage deviations are noted, with one photographed. Also tabulates a high proportion (31\%) among vultures sighted in Mana Pools over four days.

(email: pmundy@nust.ac.zw)

NOGUERA, J. C., PÉREZ, I. \& MÍNGUEZ, E. (2010). Impact of terrestrial wind farms on diurnal raptors: developing a spatial vulnerability index and potential vulnerability maps. Ardeola 57: 41-53.

The study area was the Boquerón mountain range in the province of Valencia. The Eurasian Griffon was one of the species identified as sensitive to the proposed wind farm.

(email: josec.noguera@uvigo.es)

PIETERSEN, D. W. \& PIETERSEN, E. W. (2010). Annotated checklist of the birds of Banhine National Park, southern Mozambique. Ornithological Observations 1: 7-37.

Among more than 300 species listed, were White-backed, Lappet-faced, and White-headed Vultures. All were found nesting.

(email: dwpietersen@zoology.up.ac.za) 
RASMUSSEN, P. C., CLARK, W. S., PARRY, S. J. \& SCHMITT, J. (2001). Field identification of 'Long-billed' Vultures (Indian and Slender-billed Vultures). Bulletin Oriental Bird Club 34: 24-29.

Detailed descriptions of the two species; the latter is tenuirostris and originally considered to be a subspecies of the former indicus. Has a fullpage plate of paintings, and another full-page set of eight coloured photographs.

SSEMMANDA, R. \& POMEROY, D. (2010). Scavenging birds of Kampala: 1973-2009. Scopus 30: 26-31.

Total counts have been made now and again from 1970s to 2009, on four species including the Hooded Vulture. The count for this species peaked at 424 in 2004, at four major roosting sites, and has declined to 260 in 2009. The authors attribute the decline to habitat modification (probably). (email: ssemmarich@yahoo.com)

SNYDER, N. F. R. \& SCHMITT, N. J. (2002). California Condor Gymnogyps californianus. In: Poole, A. \& Gill, F. (eds), The birds of North America, no 610, 36pp.

A review of the species, including history, fossils, and a way forward. The condor and its family Cathartidae (=Vulturidae) are placed in the order Ciconiiformes. Sections on food habits, behaviour, breeding, demography and conservation are very detailed. Includes 111 references.

(email: nfrs16426@vtc.net)

WACHER, T., NEWBY, J., HOUDOU, I., HAROUNA, A. \& RABEIL, T. (2013). Vulture observations in the Sahelian zones of Chad and Niger. Bulletin African Bird Club 20: 186-199.

Six species seen, mostly by road count surveys, over nearly $15000 \mathrm{~km}$ north and south of $16^{\circ} \mathrm{N}$, in the years 2007-2013. In total, 1076 vultures 
were seen at an average rate of 7.2 birds per $100 \mathrm{~km}$. Each species has a detailed map that includes breeding records, by half-degree squares. Rüppell's Griffon nested on five inselbergs in Chad, and also 24 instances were seen of the species nesting in trees in both countries. This lovely article includes 11 coloured photographs.

(email: Tim.Wacher@zsl.org)

WILLIAM, V. L., CUNNINGHAM, A. B., BRUYNS, R. K. \& KEMP, A.C. (2013). Birds of a feather: quantitative assessments of the diversity and levels of threat to birds used in African traditional medicine, pp. 383-420. In: ALVES, R. R. N. \& ROSA, I. L (eds), Animals in traditional folk medicine. Springer-Verlag, Berlin.

Of more than 300 species found at markets, ten were vultures. Hooded Vultures were traded in five of the seven countries investigated, being Benin, Ivory Coast, Nigeria, Togo and South Africa. Reasons for the usage of these birds is not considered. 


\section{BOOK REVIEWS}

\section{P.J. Mundy}

BAGNOLINI, C., DAVID, T., DERVIL, A., LECUYER, P. \& NEOUZE, R. (2010?). Vautours. Réintroduction et conservation dans les Grands Causses. LPO Grands Causses, Peyreleau. 37pp. (4.90€).

A beautifully produced booklet about the vultures released into the Cévennes and Grands Causses since 1981. It is dedicated to Bertrand Eliotout who was killed in a car accident in Zimbabwe in 2009. Eight pages describe the four species in the region in detail, except that it is intended to release Bearded Vultures there in the near future. Other topics are covered: history, flight, food, and several pages on relations with humans. Among many facts of interest were: each vulture emits $3.4-4.8 \mathrm{~kg}$ $\mathrm{CO}_{2}$ per week; the stomach has a $\mathrm{pH}$ of 1 to 1.5 ; some ringed birds seen in 2010 were about 35 years of age; nearly 100 griffons and six Cinereous Vultures have so far been killed by electrocution or collision with electricity lines; adult survival is $95 \%$; etc. A great summary of the project- for only five euros.

(email: vautours@lpo.fr ; www.rapaces.lpo.fr)

D'EliA, J. \& HAIG, S. M. (2013). California Condors in the Pacific Northwest. Oregon State University Press, Corvallis. xvi +208pp. ISBN 978-0-87071-700-0.

A nicely written case study, with maps and figures, and drawings by Ram Papish. There are 31 pages of references. The study is based on 81 records of the species, mostly observations, starting with the famous Lewis and Clark expedition to the Columbia River in 1805 . The first eight records are from the expedition, among which five condors were killed. The Pacific Northwest is from southern British Columbia at $50^{\circ} \mathrm{N}$ through Washington and Oregon states to northern California at $37^{\circ} \mathrm{N}$; of the 81 records there is 
one each in Idaho and Nevada. The records are exhaustively annotated in 37 pages.

The authors examine all kinds of evidence for the existence of the condor in the northwest, including fossil and anthropological. Among the latter are many quotes from the Native American tribes; quite frequently the authors call these tribes 'Indian' (e.g. p. 27) which I had always thought was not p.c.! The last observation in the northwest was in 1925 in northern California close to the border with Oregon. Chapter 4 is devoted to a very thorough investigation of the likely cause(s) of the condor's collapse, looking into poisoning, eggshell thinning, shooting, ritual killings, food supply (especially the salmon runs on the Columbia River!), etc. Poisoning is considered to be a "primary factor", possibly also lead from bullets, and direct shooting of the birds. In the end the authors try and answer why the condor went extinct in the northwest but meanwhile persisted in southern California.

At the start of the book the authors avow their hope that the northwest might play a role in the condor's recovery. Certainly they think it was a resident species there (p. 125), and even that the northwest might be a "safer environment" than southern California. In this wish they are supported by Noel Snyder in his Foreword.

Altogether this small book is a fascinating read, and exemplary as a case study approach.

FROST, P. D. (2011). Oiseaux de proie. Ces majestueux chasseurs du ciel. ML Editions, Paris. 256pp. ISBN 978-1-4454-3878-8. 13.50€.

(A French translation of the title published by Parragon Books, Bath). Vultures are described on pages 180-203, with 23 good photographs, 9 of cathartids and 14 of accipitrids. Much of the basic text is in the form of captions to the photos. On p. 203, they are Lappet-faced not Hooded Vultures. 
HILTON-BARBER, B. \& ARTHUR, L. (n. d.) [2013?]. The killer birds of Kruger. Prime Origins, Cape Town. 48 pp. ISBN 0-620-37510-8. R65.

A4 in size, paperback, coloured photos by Albert Froneman throughout, and drawings by Chip Snaddon. White-backed and Lappet-faced Vultures each have a text, photograph, and a drawing, and White-headed, Cape and Hooded Vultures a text and drawing only. Each species has a small fact box. Plus three more photos of vultures.

(www.primeorigins.co.za)

MOUZE, M. (1998). La pompe à Jules. Loubatières, Portet-sur-Garonne. 255pp. ISBN 2-86266-273-9.

MOUZE, M. (2011). Vol bivouac pour un vautour. PRNG Editions, Cressé. 339 pp. ISBN 2.914067.68.2. $11 €$

These are novels, and sub-titled "Mémoire d'un vautour fauve" and "Les réfugiés de la pompe à Jules" respectively. They tell of the adventures of Jules, hatched in the Castille region of Spain, and trapped there to be taken to the Grands Causses. This is where a very successful re-introduction of the Eurasian Griffons has occurred. Mouze is a fan of the vultures, and particularly interested in their flight. He himself is a hang-glider. (I found both these books at the Belvédère des vautours, near to Peyreleau at the gorges de la Jonte).

SERIOT, J. (2013). Guide des rapaces de France. Editions Sud Ouest, [no place]. 112pp. ISBN 978-2-81770-051-9. 8.90€

This neat little book fits snugly into a shirt pocket. The first 15 pages, with many photos (by P. Petit), discusses general characteristics about raptors. In France there are 24 species that nest regularly, including now the four species of European vulture (pp. 30-44). These four species are illustrated by 17 paintings, 4 maps and 3 drawings by the author. Each text is in 7 sections, and "Situation de l'espèce" tries to be up-to-date for populations in various areas. Curiously the adult Bearded Vulture is depicted as 
meridionalis rather than the nominate barbatus. Altogether a very handy compilation of facts about each species, following on from the earlier work (2008).

(www.editions-sudouest.com)

STEFANIAK, S. (2009). Le gypaète barbu. Editions Glénat, Grenoble. 29pp. ISBN 978.2.7234.6851.0. 6.50€.

A small book for the family, full of photographs, drawings and cartoons. Accurate information, and with many boxes of sometimes unexpected information, such as "Du grec et du latin" (p.3). Finishes with a game and a quiz. It was produced under the direction of the Mercantour National Park. (François Breton).

VADROT, C.-M. (2002). Le vautour. Actes Sud Junior, Arles. 127pp. ISBN 2-7427-3620-4. $11 €$.

This is a slim book, intended I think for a young audience. It has good illustrations by Thierry Desailly. But the text is altogether adult, and admirably describes vulture re-introduction programmes in France, dwelling at length on the griffon in the Cévennes, and briefly considering the others. Even considers the origins of the words vautour and griffon! 